\title{
UKRAINE AND THE MISSING EUROPEAN AGENDA
}

\author{
Sadri Ramabaja \\ Mr. sc., PHD Candidate, University ILIRIA, Prishtinë, sramabaja@gmail.com
}

\begin{abstract}
In Ukraine, even after the termination of the USSR, during the last two decades, ethno nationalism had not produced ethno clashes between existing ethnicities: Ukrainians, Tatars and Russians. The coexistence between these and other ethnic groups seemed more likely in the Crimean peninsula.

The last year marked an end to the status quo. The Ukrainian government lost control over Crimea and other eastern regions. A new political reality is being created in this part of Ukraine. As the political scientist Robert Jackson said, Ukraine is turning into a "quasi-state". It is gradually turning into a country, where most territories remain outside the center's control, ungoverned.

In Ukraine's case, the EU has proven that it can carry out historic missions. The mediatory mission of the three foreign ministers, from Germany, France, and Poland, showed the first fruitful results - avoiding the clashes between the West and Russia.

However, now after one year, can we still say that the EU has a consistent agenda for Ukraine? If so, Ukraine will soon realize that the agenda, with its motto for peace and freedom, has its costs. How should we understand this "lack of an agenda"? Can we speak of a geopolitical relocation or of retrieval to the dormant alliances? The conservative German circles are showing understanding towards Russian and Serbian interests. This stand feeds the idea of promoting the return of the Russian-German "dormant tradition". This idea is destined to fail, since it is not in accordance with Berlin's interests. Therefore it can be concluded that it is time for the revival of the typical German rationalism in the field of political opinion, in favour of drafting a European agenda for Ukraine, as well as for the Southeast of Europe.
\end{abstract}

Keywords: Ukraine, Crimea, European agenda, German geopolitics, rationality of German political thought.

\section{INTRODUCTION}

The collapse of the Modern Russian "Empire", which in the political history of the twentieth century's was baptized as the Union of Soviet Socialist Republics, two decades ago brought into real life of geopolitics the Ukraine as an independent republic, with its borders which were set during the era when this "Empire" was in its prime. Unlike other former republics of the region, in Ukraine during those past two decades, the ethno nationalism had not yet reached the level of clashes between existing ethnic groups such as: Ukrainians, Tatars and Russians. A sort of coexistence between these and other smaller ethnic groups, still seemed possible in the Crimean peninsula, where a good part of the population were Russian and where Russian submarines continued to be deployed. Even a superficial view of the Ukrainian map would demonstrate the strategic position of this country, for NATO as well as for Russia. 
In the east the country borders with Russia, while gas pipelines towards Europe go right through Ukraine. Through these pipes almost $80 \%$ of the Russian gas passes. The main income of dollars in the Russian economy is, de facto, precisely thanks to this transportation. The famous humus land of Ukraine, Chernozem, which comprises almost two-thirds of Ukrainian land, is regarded as the most fruitful soil in the world. Meanwhile the region which is irrigated by rivers Dniestria and Dnjepr is the only in the world, where the so-called "sweet" soil is located, and it has a width of 500 kilometers. This land is regarded as the greatest asset of the country, as it ensures good crop of wheat. The greatest entrepreneurs from the west, in the field of agricultural business, such as Monsanto, Cargill, AMD and Kraft Foods, relying on the end of internal political struggles, have started to lay hands on this Ukrainian wealth. (Amerikanische Handelskammer in der Ukraine).

In eastern Ukraine, which borders Russia completely, live somewhere over 15 million Russian citizens, meanwhile, since it is the most fertile region it is regarded as the granary of Eastern Europe. In 2009 Ukraine was, after the US and the EU, namely before Russia, the biggest producer of wheat crops in the world. (Press Trust of India, 2009: „Ukraine Becomes World's Third Largest Grain Exporte«) Adding to this wealth also the large stock of various metals, we can imagine more realistically the importance Ukraine has for each of the existing powers of the world. Therefore we can conclude that 2004 marks the historic turn for Washington, as the year when the most strategic steps towards the path of "Full Spectrum Dominance" were taken, as on land, oceans and space, emphasizes rightly the Pentagon. Let us recall one fact, in 1919 Halford John Mackinder, the father of British geopolitics, wrote in his famous Democratic Ideals and Reality (in English: "democratic ideals and reality" - zu Deutsch: Demokratische Ideal und Wirklichkeit): "Those who govern the Eastern Europe own the heart of the earth, own the islands of the world (he called this way the Eurasia) - those who govern the islands of the world, own the world". (Ferati, Haxhi, 2013. pp. 56-57). Ukraine with over 46 million inhabitants presents the most interesting market for German manufacturers, soon after the Russian one. Up until the beginning of the crisis, there were over 2,500 German firms that had set up their subsidiaries or had joined their capital with counterparts in Ukraine and were present in the Ukrainian market. Major German brands, such as Leoni, ODW, Metro, Heidelberg Cement, Rhenus Revival, DHL and REMONDIS are already present in the Ukrainian market.

\section{THE STATUS QUO'S END}

The past year (2015) ended the status quo in this peninsula. Meanwhile, Ukraine's new government has lost control over Crimea. In the clashes between the parties, the radical pro-Russian forces in Simferopol, within a short time seized the regional parliament. In an urgent procedure that resembled scenarios of Serb National Council of Northern Kosovo, the pro-Russian forces, at the conclusion of the coup, elected the new prime minister of Crimea, which does not recognize the government of Kiev.

The Russian military forces have already been put into operation. The Simferopol Airport is already in the hands of the Russian army. In the streets and squares of the city, Russian tanks are parading. The city is continuing to be held captive. In this part of Ukraine, with the speed of light, a new political reality was created. It seems that this new reality, was the product of the political naivety of the nationalist opposition highlighted with fascistic tones, as well as the perfect Russian cynicism.

Within hours, when in Kiev after the departure of pro-Russian president Viktor Yanukovych, nationalism had flooded and overcome squares and streets of the Crimea, killing the political rationality; a decision was being made to abolish the Russian language as an official language in the region of Crimea, thus giving a sort of "legitimacy" to the Russian intervention.

In this race of positioning, big underdogs appear to be, first of all, Tatars deported during Stalin's period, accounting for more than $12 \%$ of the population. Meanwhile, it remains to diplomacy to save as much as possible that can be saved. This is why only within a very short period, the Foreign Secretary of the United States, John Kerry and German Foreign Minister Frank-Walter Steinmeier, met four times. The latest meetings were to promote additional evidence of the weight Germany has gained in regards to transatlantic relations. Statement of US Secretary John Kerry in this regard, that "the US are glad about the increased role of Germany in solving problems of global nature," given to Reuters speaks a lot.

The flow of the democratic revolution in Ukraine was extremely fast. It appears that victorious in its conclusion, will be many parties. The EU, with an engine power as Germany at the forefront, this time has proven that it can conduct instant historical missions. The intermediary mission of three foreign ministers, those of Germany, France and Poland, gave the appropriate results. The country was averted from the abyss of civil war, a state which seemed quite inevitable which would have been caused by the authoritarian government of Viktor Yanukovych, but most importantly a possible collision between Europe and Russia was avoided. 
However, can we really say that with this action, the European agenda for Ukraine proved successful? Of course not.

The EU should to a certain extent even be self-critical, why Ukraine was almost in civil war and on the verge of having its eastern parts invaded by Russia. Irresponsiveness of the EU and the cold attitude of the International Monetary Fund gave time and opportunity to dictator Yanukovych for calculations. Ukraine is already facing a financial collapse. Democracy needs to be strongly supported and people to taste it through welfare increase. This would be an additional lesson for the EU in steps expected towards expansion to Eastern Europe, and of course in relation to its agenda towards Ukraine.

\section{UKRAINE - A HOSTAGE TO GEOPOLITICS}

Ukraine and the EU will meanwhile be forced to admit, even painfully, the loss of the eastern regions, where Russia has the last saying, as it happened similarly with Crimea. This process seems to be inevitable. The main mission is the creation of so-called "Novaya Rusia" everywhere where ethnic Russians live in former republics of the USSR. At first glance it seems that it is not completely in the interest of Russia to "plunge" into war for these eastern parts of Ukraine will all the active public dimensions. In this case Russia will be clearly seen as an aggressor, since it will march in territories of an independent country. However, Russia remains focused in defending its interests in Ukraine by any means. Therefore it seems that the higher cost will be paid by ethnic Russians of Eastern Ukraine.

It is already clear for Eastern Ukraine's ethnic Russians that only through parallel routes like: active resistance and expression of political will (by referendum for independence), will find the support of the Russian Federation and create chances for complete detachment from Kiev. For this geostrategic purpose, they are based on the speech of Russian President Vladimir Putin, held on $18^{\text {th }}$ March 2014 in the Kremlin before the deputies of the Russian Duma, the members of the Federal Council, the governors of the country and representatives of the so-called civil society, a speech that had to do with the request of the Republic of Crimea and the city of Sevastopol to be 'accepted as an integral part of the Russian Federation.

Both these roads, them, the ethnic Russians of eastern Ukraine, are following fanatically. De facto after the referendums already held, eastern Ukraine's regions are under the full control of Moscow. Any change of this course with long-term detailed plans, it is clear, would lead to clashes with NATO as well as an inevitable positioning of its forces on the borders with Russia, as the worst case scenario for the Kremlin.

In this open race for dominance, the battle is won by those with the greatest patience. Eastern Ukraine through the so-called status of a high degree Autonomy will be established as a separate political entity within Ukraine, while its orientation will be Moscow.

It seems that Ukraine only now will notice that this agenda, the motto of which is peace and freedom, has its cost. Geopolitics as a consecration for dominance and expansion of territories was considered as a thing of the past - passé. However, time is proving that at the beginning of the $21^{\text {st }}$ century, this concept is experiencing complete renaissance. What Russia is doing in Ukraine is a proper example. Political clashes in Kiev between extreme right, who were labeled as neo-fascist groups and leftist pro-Russian formations, whose main topic could be the fight against corruption or the building of democratic order and the rule of law, soon left the country to the international fight for power and influence. In an editorial in the Financial Times, published on $23^{\text {rd }}$ February 2015, is stated that all that was happening for months in Ukraine is seen as an interdependence of geopolitical interests. For almost quarter of a century, a certain territory of Ukraine was the subject of collision between the EU and Russia, which de facto is not nothing but a geopolitical war between the Kremlin and the West". In 2008 there was a failed attempt by US President George W. Bush, to pull into NATO the two former republics of the USSR - Ukraine and Georgia. "And now again Maidan's Revolution offers all parties a second chance, through resolution of the status of Ukraine to review the dividing line of Europe." Ukraine with over 46 million inhabitants, with a strategic position, positioned between Russia, Europe, the Black Sea and Caucasia is back again at the center of geopolitical and geostrategic interests. It is gradually de facto becoming a hostage to geopolitics. Time is proving that Ukraine is resulting as a battleground, where interests of Russia, the EU and the US are clashing. But just like Albania on the verge of World War II that had become hostage to the "game of two opposing blocks of the European diplomacy" (one of these blocks was led by Italy and the other by France), in the same way Ukraine today is being harmed because of the collision of Russian and American interests, as well as the lack of a set European agenda. All parties are aware that "Eurasia remains further a springboard, on which even in the future, the battle for global domination will depend." (Schwarz, Peter. 2015)

As the political scientist Robert Jackson would say, Ukraine de facto is turning into a "quasi-state", by 
considering as such the zones that are internationally recognized as sovereign countries, but in essence they represent ungoverned territories, just like we have the case of few places in the southeast of Europe (Bosnia the most obvious example). Quasi-states have all external attributes of statehood - they are internationally recognized by other states, occupy seats in the UN and various international organizations, as well as maintain diplomatic relations with foreign countries (ex. by being the host of embassies of other states). However, within the territory, the government of the country does not enjoy sovereignty; it doesn't exercise authority in all its territory as a result of administrative weaknesses of the government or internal conflicts. (Pula, Besnik. 2015), as it is the obvious case of Ukraine.

Jackson, while using the term quasi-state had into account countries of the African sub-Sahara like Somalia, Liberia, Congo etc. which even though existed and exist in the international map as sovereign states, are not governed as such because of civil wars, ineffective governments and other deep politico-territorial divisions. With its military actions in the Crimea peninsula, Moscow has openly violated the sovereignty and integrity of Ukraine. But despite this bitter fact, western diplomacy can call upon the 1994 Agreement, which was reached between Russia, the US and Great Britain, that had to do with ensuring the sovereignty of Ukraine, and the Ukrainian government agreed to hand over its nuclear weapons. Based on this agreement, Moscow would have to be forced to respect the sovereignty of Ukraine. Otherwise the European agenda over Ukraine would be seen as inexistent, respectively incomplete.

\section{THE ANNEXATION OF THE CRIMEA- A COMPLETED ACT}

The strategic military grip of Russia through the attraction of Georgia and Ukraine into NATO's embrace now looks like an unfeasible attempt in a military way. Therefore the issue proceeds to the negotiating table. The passage that leads Russia to the Black Sea obviously going through Crimea which until recently was part of Ukraine, seems that is and will remain fully under Russian control. Russia also through the support given to Russian rebel forces in Ukraine proves that is not yet prepared to defer and that will reflect in the loss of its influence in Ukraine. Indeed it has already proven that

Russia is focused in provoking even bigger clashes in order to keep its influences over Ukraine.

The German Chancellor apparently achieved to manage the euro crisis in the Eurozone, to postpone the issue of northern Kosovo in order to suit Greek interests (leaving it on purpose as a "frozen conflict" by improvising with the so-called agreement of $19^{\text {th }}$ April 2013 and $25^{\text {th }}$ August 2015 thus protecting the Serbian interests in Kosovo), while in case of facing a more serious clash, such as the annexation of the Crimea by Russia and taking control of a good part of eastern Ukraine, she, as well as Europe, again appear in their real light - extremely unstable, by considering the occupation of Crimea and Ukraine's eastern parts inhabited by Russians, as fait accompli. This duality has to do with the lack of a clear vision of Germany regarding its foreign policy, as rightly noted by Steven Hill, the author of the book 'Europe's Promise: Why the European Way is the Best Hope in an Insecure Age'.

In the political history of Germany after World War II, each of the chancellors gave its seal, by becoming a leader and influential personality in the global plane. Let us remember the impact of chancellor Villy Brandt with his vision of German policy in relation to the East or Helmut Kohl who is marked in history as the chancellor who made the unification of Germany. Angela Merkel has an ideal chance to act in southeast Europe by sending clear messages to Belgrade regarding the north of Kosovo, as well as to Skopje on the issue of the name of the State and the co-existence with Albanians there, but with aligning with Greece too, all these, in accordance with the processes of the region's integration into NATO and the EU, and thus the full restoration of German interests in the region. Through this new German course, the chancellor could go down in history as a true visionary, by fully returning the Balkans to the old continent.

By fully returning Western Balkans to the Euro-Atlantic family, Europe would significantly contribute towards strengthening its transatlantic relations as a necessity for a successful showdown against Russia's geopolitical ambitions.

\section{GEOPOLITICAL REPOSITIONING OR RETRIEVAL TO THE DORMANT ALLIANCES?}

Policies that were followed by her predecessor, Gerhard Schroeder, in relation to strengthening of the economic relations with Russia, are already proving unsuccessful. Meanwhile, the new German course diligent in relation to the prosperity of reforms within the EU, which proved to be more supportive of the idea for Europeanization of Germany than Germanization of Europe, as was seen by Eurosceptics, could gain weight if Berlin will focus more on solving the pending issues in Illyrian Peninsula. Is there any chance that this course gets pushed by Social Democrats, as a partner with their experience in the pro-European 
orientation? Just like the differential stance of German Foreign Minister Frank Walter Steinmeier (FrankWalter Steinmeier) also the attitude of the leader of the Social Democrats, partners in the current government of Germany, Sigmar Gabriel, is expected to significantly impact on the course of the Chancellor's foreign policy, by giving it a new direction. Without such an agenda, we cannot speak for a Germany with new, more dynamic ideas and for a Europe of the $21^{\text {st }}$ century.

In the north of Kosovo, it has been some time now that the Serbian authority is set through the so-called Serbian nationalist groups. This was revealed even openly on the occasion of the parade of the Serbian gendarmerie during Sunday's protest in Mitrovica.

Seven conditions that official Berlin had set for Serbia prior to granting the candidate status for the EU, way before the so-called technical talks between Pristina and Belgrade, were in accordance with the German vision for the region, a commitment for stability and long-term peace in the region. What happened in the meantime? Where did this compromise for Serbia's position in the north come from? This kind of understanding in relation to the current Serbian policy, which comes somewhat as an extension of the open sympathy of various circles in the German policy for Putin's politics in the Crimea and in general in Ukraine, ranging from conservatives such as Alexander Gauland's and Peter Gauweiler - and up to those like the previous two former Social Democrat chancellors like Gregor Gysi and Sarah Wagenknecht, speaks clearly about the existing dualism in the German foreign policy.

This tolerance for the interests of Russia's security, which is reflected by a tame treatment of Serbia, also sheds light on the German weaknesses in relation to a realistic assessment of the potential danger faced by a group of countries in East and Southeast Europe. Consequences that would produce this kind of German "understanding" for Russian security on one side and Serbian in north of Kosovo on the other side, can be of unpredictable proportions for Germany but above all for Illyrian Peninsula, Poland and the Baltic republics. Poland can never forget how agreements were made between Russia and Germany, on their expense, since the end of XVIII century up to the famous pact between Hitler and Stalin (1939). While Albanians also, in their historical memory, have stacked the tragic decisions of Berlin Congress (1878) to separate the Toplica ( 8 towns and over 600 villages) in favor of Serbian interests in this part of the Albanian parts that today is called as Southern Serbia; and Hoti, Gruda, Tivat and Ulqin in the favor of Montenegro!

Now we are witnessing the return of geopolitics and thus the repositioning of states into politic blocs, while Moscow still continues to serve to a set part of nations in Eastern Europe, as a point of gravity. "In eastern Ukraine, pro-Russian separatists bear the flag of 'pansllavist union' of the believers of Orthodox Church; in the Middle East, the Islamic State and terrorist groups are urging Muslims to fight for their caliphates. The Balkan is at the crossroads of Central Europe, Asia and the Middle East. If the region remains in a strategic vacuum, it could easily be filled by actors who may not be preferred by the EU." (Reka, Blerim, 2015).

This would be the biggest historical mistake if the missing European agenda for Ukraine, is intended to be corrected in the Eastern Europe in favor of Serbia and with the hope that in such a manner, Russia would be held far away out of this eruptive area.

The understanding offered to the interests of the Russian security and its ally Serbia, by German conservative circles, quite well have to do with geopolitical repositioning card. This attitude feeds the ideas of promoting the course that would lead to a new German position in favor of the revival of a dormant tradition between Russia and Germany.

My hypothesis has nothing to do with what is related to geopolitical restructuring of Europe in the first two decades of the XXI century.

If we would bear in mind the conclusion of Klaus-Achim Bosler's that the geopolitical structure of Europe will undergo drastic changes, (Bosler, Klaus-Achim, 2015) then it seems that we are at the beginning of this change.

This change has to do essentially, as would J.Fisher state, "... to elect between self-determination and external domination. The way how Europe treats this issue will determine not only its own destiny but also that of the West." (Fischer, Joschka, 2015).

Rebalancing of these positions would turn its attention to the real intentions of German geopolitics: strengthening Germany's priorities in economic and political level within the EU; The exercise of German influence in East and Southeast Europe; and maintaining Russia under control in the framework of the security, without violating the economic interests etc. All this is in the immediate interest of Germany to be in total agreement with the United States while these, the agreements, nevertheless to be in line with specific German interests. 


\section{CONCLUSION}

Obviously agendas of this nature are doomed to fail, as they not only won't be met with sympathy by the official Berlin, but neither by the people, whose interests are again put at risk. And the fact that this course would bring the Atlantic Alliance and the European Union before the greatest historical challenge, makes it impossible, by accelerating the differentiation between the West and Russia. Viewed in retrospect, this difference not only cultural and political between the West and Russia, appears almost as the core of basis of history that makes the West more Western precisely through appearance of its tradition in terms of political values, that are reflected in its plural political system, the emphasized culture of progressive individualism, the rule of law and human rights, national sovereignty and representing democracy.

Joschka Fischer, the former German foreign minister, concludes that with the military invasion of Russia and the annexation of the Crimea, and the war that followed in eastern Ukraine, the President Vladimir Putin has made it more than clear that he does not intend to respect the inviolability of borders and the supremacy of international legal norms. It is time for Europeans to end their utopian thinking for an order in the continent defined by the rule of law. (Fischer, Joschka, ibd.)

The transatlantic west, part of which already is the nucleus of the Albanian nation and state (Republic of Albania), has already taken into consideration these elements of historical tradition. During the talks between the EU and Kiev, but also Skopje, Tirana, Prishtina ... in relation to the terms of the Association Agreement and its candidacy for EU accession, had raised hopes and optimism that these countries are no longer in front of an alternative: Brussels or Moscow. It may be that Belgrade, as has played for more than a century on the card with the West but also with Russia has created illusions in Berlin, but this does not mean that the game can continue indefinitely. This historic momentum should serve, not only Berlin but also in Brussels as the capital of our common Europe. Therefore, to achieve this momentum, there is an urgent need for the revival of the typical German rationalism in the field of political thought.

\section{REFERENCE LIST}

Amerikanische Handelskammer in der Ukraine, Chamber Members, at: http://www.chamber.ua/.

Press Trust of India, 2009: “Ukraine Becomes World's Third Largest Grain Exporte”, at: http://blog.kievukraine.info/2009 1201 archive.html.

Ferati, H. (2013).“Gjeopolitika dhe Gjeostrategjia”, Prishtinë, p. 56-57;

Halford J. M. (1942), Democratic Ideals and Reality, Henry Holz and Company, p.150.

V. Putin, (2015).Zum 70. Jahrestag des Sieges über den Faschismus, at: http://geopolitik-

studien.de/putins-rede-zum-beitritt-der-krim/

Schwarz, P. (2015), Die geopolitische Dimension des Umsturzes in der Ukraine,

at: https://www.wsws.org/de/articles/2014/02/27/ukra-f27.html

Brzezinski, Z. (2014). "The Grand Chessboard. American Primary and Its Geostrategic Imperatives", deutsch: "Die einzige Weltmacht - Amerikas Strategie der Vorherrschaft", Fischer Taschenbuch Verlag, p.15/16

Pula, B. (2015) E ardhmja si kuazi-shtet, at: http://sbunker.net/teh/48807/e-ardhmja-si-kuazi-shtet/

Reka, B.(2015). The Western Balkans peace: Europe's unfinished mission,at:

http://www.worldreview.info/content/western-balkans-peace-europes-unfinished-mission

Klaus-Achim Bosler. (1997). Neu E Ansätz E De R Politische N Geographi E Un D Geopoliti K, at: https://www.erdkunde.uni-bonn.de/archive/1997/neue-ansaetze-der-politischen-geographie-undgeopolitik/at download/attachment.

Fischer, J. (2015), The Return of Geopolitics to Europe, at: https://www.projectsyndicate.org/commentary/geopolitics-returns-to-europe-by-joschka-fischer-2015 